\title{
A Red Shrimp, Farfantepenaeus brasiliensis (Latreille, 1817), Larvae Feeding Regime Based on Live Food
}

\author{
Gabriela Gaxiola ${ }^{1,{ }^{*}}$, Pedro Gallardo ${ }^{1}$, Nuno Simôes ${ }^{1}$, Gérard Cuzon $^{2}$ \\ ${ }^{1}$ Unidad Multidisciplinaria de Docencia e Investigación, Sisal, Facultad Ciencias, UNAM, Yucatán, \\ México \\ ${ }^{2}$ Centre Océanologique du Pacifique (COP) IFREMER, BP 7004, Taravao, Tahití, French Polynesia \\ *: Corresponding author : Gabriela Gaxiola, email address : $\underline{\text { mggc@fciencias.unam.mx }}$
}

\begin{abstract}
:
Red shrimp, Farfantepenaeus brasiliensis, larvae's response to different concentrations of live foods (diatoms Chaetoceros gracilis: $20-100 \times 10^{3}$ cells $/ \mathrm{mL}$; flagellate Tetraselmis chuii: $2-10 \times 10^{3}$ cells $/ \mathrm{mL}$ and Artemia nauplii [NA]: $1-5 \mathrm{NA} / \mathrm{mL}$ ) was investigated in three experiments. Experimental assessments were based on four variables: survival rate, weight gain, development index (DI), and resistance to salinity stress. A combination of $C$. gracilis $80 \times 10^{3}$ cells $/ \mathrm{mL}, T$. chuii $2 \times 10^{3}$ cells $/ \mathrm{mL}$, and Artemia $4 \mathrm{NA} / \mathrm{mL}$ provided the best experimental response. Specifically, F. brasiliensis larvae fed with the above-mentioned optimal concentrations of microalgae and Artemia grew faster and reached the postlarval stage in less time (168 h) than larvae in other feeding regimes evaluated. The effect of C. gracilis concentration on larval growth, survival, and the DI demonstrated that microalgae-based foods could be a highly productive alternative to more traditional aquaculture feeding regimes.
\end{abstract}


The spatial distribution of Caribbean red shrimp, Farfantepenaeus brasiliensis, extends from North Carolina and the Florida Keys in the north to the Río Grande do Sul, Brazil in the south, and encompasses the southern Gulf of Mexico (including Yucatan), the West Indies, Bermuda, and the Caribbean coast of Central and South America (Perez Farfante and Kensley 1997). F. brasiliensis has been recognized as an excellent candidate species for aquaculture (Anguiano 1999) because populations remain abundant in the wild, growth rates under culture conditions are relatively good, and maximum adult size is large comparable to other penaeid species.

Although this species could be effectively farmed, efficient larval rearing production techniques need to be developed. Penaeid larvae inhabit coastal waters where they prey on a variety of phytoplankton and zooplankton. Under laboratory conditions, cultivation of such plankton communities has proven unreliable and impractical. Hence, a limited array of food organisms, mainly selected strains of microalgae and Artemia NA, has provided the basis for indoor shrimp larvae production; although, nematodes and ciliates have also been exploited with moderate success (Leger and Sorgeloos 1992).

Because shrimp larvae begin exogenous feeder by ingesting phytoplankton (Jones et al. 1997), several algae species were cultured for penaeid larvae culture. It included diatoms (e.g., Chaetoceros spp.), which are among the best food for early shrimp larvae stages, as well as other species e.g. flagellates such as Tetraselmis spp. to enhance the nutritional profile and to provide an adequate size range between 8-12 x 7-10 $\mu$ exclusive of the setae (Simon 1978; Brown 1991). Consequently, the use of two algal strains as a food source, generally a diatom and a flagellate, has been a popular option (Leal et al., 1985; Aquacop 1983; Gallardo et al. 1995). Although Tetraselmis spp. alone were successfully used for penaeid larvae (Aujero et al. 1983; Souza and Kelly 2000), a mixture of algae gained popularity due to the fact that a single algae could not fulfill all larval-stage lipid requirements. Lipids provide endogenous energy reserves during the embryonic and larval periods in decapods crustaceans (Kattner et al., 1994), because they possess little or no ability to biosynthesize n-3 highly unsaturated fatty acids, HUFA's (Teshima 1997). Importantly for aquaculture, the composition of both C. gracilis and $T$. chuii contain these HUFA's (Brown et al. 1997). Artemia, probably the most frequently-used food organism in aquaculture because of its high nutritional value (Sorgeloos 1980) and good fit with the raptorial habit of shrimp larvae, offers another viable source of HUFA's (Emmerson 1980, 1984; Yufera et al. 1984; Lovett and Felder 1989; Rodriguez et al. 1994).

The purpose of the present study was to determine the optimal feeding regime for $F$. brasiliensis larvae by testing the impact of various concentrations of $C$. gracilis, $T$. chuii, and Artemia NA on survival, growth and development index. The quality index was also calculated based on the resistance to salinity stress of the postlarvae harvested from the different treatments.

\section{Material and Methods}

\subsection{Source of Larvae}

F. brasiliensis larvae used in each experiment were obtained from a single spawning of naturally inseminated females harvested from the wild. They were captured at a depth of 42 to $67 \mathrm{~m}$ near Isla Contoy, Quintana Roo, Mexico. Females were unilaterally eyestalk ablated to accelerate gonad maturation. Eggs were collected and placed in a small tank to obtain the nauplii that were harvested from the hatching tank at stage $\mathrm{N}_{1-2}$. 


\subsection{Breeding Conditions of the Larvae}

Food components were collected from two sources. Algae were cultured in a Guillard medium and given to the larvae during the growth culture's stationary phase. Nauplii (NA) were obtained from cysts of Artemia franciscana collected from Great Salt Lake Brine shrimp (Prime Artemia Incorporatzio, Utah, U.S.A).

The experiments to determine the optimum concentrations of $C$. gracilis (Experiment 1 ) and $T$. chuii (Experiment 2) involved monitoring shrimp larvae from the Protozoea ${ }_{1}$ stage $\left(\mathrm{Pz}_{1}\right)$ through the postlarvae ${ }_{1}\left(\mathrm{PL}_{1}\right)$ stage. Experimental tanks were initially stocked to a density of $100 \mathrm{NA} / \mathrm{L}$.

The experiment to determine the optimum concentration of Artemia NA (Experiment 3) involved monitoring larvae from the mysis I $\left(M_{1}\right)$ stage through the $\mathrm{PL}_{1}$ stage. This experiment involved stocking $10 \mathrm{~L}$ conical bottom fiberglass tanks with $4 \mathrm{~L}$ seawater containing an initial larval density of 50 mysis per liter (volumetric count). Survival rates were estimated using $1 \mathrm{~L}$ round bottom glass flasks kept in a thermostatically controlled water bath $(28 \pm 0.5 \mathrm{C})$ and aerated using a glass rod with 2-4 bubbles/second. Flasks were filled with $500 \mathrm{~mL}$ of seawater.

Natural seawater used in the experiments was filtered at $5 \mu \mathrm{m}$ and treated with EDTA (10 mg/L) recycled through a 1200-L/h capacity power filter (Fluval 403 Hagen, Phyladelphia, Pensilvania, U.S.A) with UV sterilization, was maintained in a 1100L tank for 5 hours prior to use. Temperature, salinity (ppt), oxygen $(\mathrm{mg} / \mathrm{L})$, and $\mathrm{pH}$ were measured and recorded twice a day. $50 \%$ of the water was exchanged in the tanks everyday between $M_{1}$ and $\mathrm{PL}_{1}$ stages and no antibiotic was added.

\section{Experiment 1}

To determine the optimum concentration of diatoms, $F$. brasiliensis larvae were fed five different concentrations $\left(20 \times 10^{3}, 40 \times 10^{3}, 60 \times 10^{3}, 80 \times 10^{3}\right.$ and $100 \times 10^{3}$ cells $\left./ \mathrm{mL}\right)$ with three replicates for each. During $\mathrm{Pz}_{2}-\mathrm{Pz}_{3}$ stages, the concentration of flagellates, $\mathrm{T}$. chuii was maintained at a constant level $\left(5 \times 10^{3}\right.$ cells $\left./ \mathrm{mL}\right)$. Then, during the period from $P z_{3}$ to $P L_{1}$, the concentration was adjusted to $7 \times 10^{3}$ cells $/ \mathrm{mL}$ and maintained at that level. The flagellate concentrations followed experimental levels used previously for pink shrimp, F. duorarum larvae. The addition of Artemia NA began after the onset of the $M_{1}$ stage and continued to $\mathrm{PL}_{1}$ stage (Lopez 1998).

\section{Experiment 2}

To determine the optimum concentration of flagellates, larvae were fed five concentrations of $T$. chuii $\left(2 \times 10^{3}, 4 \times 10^{3}, 6 \times 10^{3}, 8 \times 10^{3}\right.$ and $10 \times 10^{3}$ cells $\left./ \mathrm{mL}\right)$, each with three replicates. The results obtained in the Experiment 1 were taken into consideration and the $C$. gracilis concentration that provided the best results $\left(80 \times 10^{3}\right.$ cells $\left./ \mathrm{mL}\right)$ was used in all treatments from the $\mathrm{Pz}_{1}$ stage to the $\mathrm{PL}_{1}$ stage. Artemia NA counts were adjusted accordingly (López 1998).

\section{Experiment 3}

To determine the optimum concentration of Artemia NA, larvae were fed five different concentrations $(1,2,3,4$, and $5 \mathrm{NA} / \mathrm{mL})$ with three replicates each. $\mathrm{P} \mathrm{z}_{3}$ stage larvae were placed in tanks at an exact density of 50 per L. Again, diatoms were provided at a concentration of 80 $x 10^{3}$ cells $/ \mathrm{mL}$, following the results achieved in experiment 1 ; where as, flagellate concentration was modified based on results obtained in experiment 2 and was provided at a density of $2 \mathrm{x}$ $10^{3} \mathrm{cells} / \mathrm{mL}$. Finally, when larvae molted to the $\mathrm{M}_{1}$ stage, Artemia NA were added.

\section{Feeding}


Larvae were fed every 12 hours at 08:00 and 20:00 following the feeding regime established by Gallardo et al. (1995) for L. setiferus. During the experiments, C. gracilis, T. chuii, and Artemia NA concentrations were adjusted to stick on following schedule (Seafdec 1984):

$$
A V=\frac{T V(W C C-R C C)}{F C C-R C C}
$$

where $\mathrm{AV}$ is volume to add; TV is tank volume; WCC is desired cell concentration; RCC is residual cell concentration; and FCC is food cell concentration.

The larval population's development stage in each tank was assessed using a DI (Villegas and Kanazawa 1979). DI, also called metamorphosis rate, was calculated based on the daily observation of 5 larval stages randomly selected from each experimental $10 \mathrm{~L}$ tank using the ranking formula:

$$
D I=\frac{\left(\sum A\right)}{N}
$$

where $\mathrm{A}$ is the absolute value given per number of larvae of each sub-stage examined, and $\mathrm{N}$ is the total number of larvae in each sample. Absolute values assigned for each substages were protozoea $_{1}=1 ;$ protozoea $_{2}=2 ;$ protozoea $_{3}=3 ;$ mysis $_{1}=4 ;$ mysis $_{2}=5$, mysis $_{3}=6 ;$ postlarvae $_{1}=7$.

\section{Growth}

Growth was determined by using the total length measurements from 5 randomly selected larvae from each experimental $10-\mathrm{L}$ tank. Measurements of $\mathrm{Pz}_{1}$ stage larvae were made from the tip of the cephalothorax to the end of the telson, including the spines. $\mathrm{Pz}_{2}$ and $P z_{3} s t a g e$ larvae were measured from the front of the rostrum to the end of the telson, excluding the spines. For the mysis stage, the larvae were measured from the anterior edge of the cephalothorax to the end of the telson. Once measurements had been recorded, the larvae were dried at $60 \mathrm{C}$ and weighed in pools consisting of 5 larvae grouped by tank and stage. The daily growth coefficient (DGC) was used to estimate the weight gain (Bureau et al. 2000), assuming linear weight increase over the short period of larval development.

$$
\mathrm{DGC}=\left(\frac{\sqrt[3]{W_{f}-\sqrt[3]{W_{i}}}}{t(\text { days })}\right) 100
$$

where Wf is the final dry weight; Wi is initial dry weight; and t is time in days to reach postlarval stage 1.

\section{$\underline{\text { Survival (S) }}$}

Survival was calculated and expressed in percentage based on the final number of larvae in the $1 \mathrm{~L}$ flasks.

\section{Quality Index (QI)}

Three groups of thirty postlarvae $\left(\mathrm{PL}_{2}\right)$ organisms were randomly selected from each of the treatments and placed in 2-L glass flasks with previously filtered, sterilized, and aerated seawater. To reduce stress, postlarvae were kept in these containers for a minimum of $1 \mathrm{~h}$ with constant aeration at $28 \pm 1 \mathrm{C}$. Then, an osmotic shock was achieved by the addition of distilled water so that salinity decreased from 35 to $25 \mathrm{ppt}$. Postlarvae were counted and the Quality 
index (QI) was calculated as the percentage of organisms that survived this shock. QI was calculated for each treatment.

\section{Statistical Analysis}

A one-way ANOVA was performed on the growth (DGC, AGR), development index (DI), and quality index (QI) data to detect significant differences among treatments in each experiment. Where significant differences were detected, a test of Tuckey for means comparison was applied (Zar 1996). Data expressed as percentages (survival) were transformed to arcsine before ANOVA analysis taking into account a significance level of 0.05 .

\section{Results}

\section{Experiment 1}

Larval weight and length gain are presented Table 1 after feeding with different diatom concentrations. For DGC, the larvae fed $20 \times 10^{3}$ cells $/ \mathrm{mL}$ had significantly lower values when compared to all other treatments. There was also a clear trend in which DGC increased with the C. gracilis concentration up to $80 \times 10^{3}$ cells $/ \mathrm{mL}$. Highest absolute growth rate (AGR) were reached in larvae fed 80 and $100 \times 10^{3}$ cells $/ \mathrm{mL}(P<0.05$, Table 1$)$. In relation to DI, after $24 \mathrm{~h}$, there were already significant differences among treatments. The $20 \times 10^{3}$ cells $/ \mathrm{mL}$ treatment produced a low DI (Table 2) as compared with other treatments. After $96 \mathrm{~h}$, larvae fed $80 \times 10^{3}$ and $100 \times 10^{3}$ cells $/ \mathrm{mL}$ reached the $M_{1}$ stage. After $168 \mathrm{~h}$, these two treatments led to postlarval stage. In comparison, only $53 \%$ of larvae fed $60 \times 10^{3}$ cells $/ \mathrm{mL}$ reached the $\mathrm{PL}_{1}$ stage at the same time. After 10 days $\left(240 \mathrm{~h}\right.$ ) the larvae fed $20 \times 10^{3}$ cells $/ \mathrm{mL}$ (Table 2) remained at the $\mathrm{M}_{2}$ stage indicating a significant delay in development after $216 \mathrm{~h}$. Survival rates of larvae significantly increased with $C$. gracilis concentration. The significant lowest survival was observed with the larvae fed the lowest cell concentration $\left(20 \times 10^{3} \mathrm{cells} / \mathrm{mL}\right.$; Table 1$)$. Postlarvae tested through salinity shock showed significantly higher resistance when fed $60 \times 10^{3}$ cells $/ \mathrm{mL}$ while organisms fed $20 \times 10^{3}$ cells $/ \mathrm{mL}$ showed lowest resistance (Table 1). Postlarvae fed $100 \mathrm{x}$ $10^{3}$ cells $/ \mathrm{mL}$ show no difference as compared with those fed $80 \times 10^{3}$ cells $/ \mathrm{mL}$.

\section{Experiment 2}

The concentration of C. gracilis (Table 1) that provided the best results in Experiment $1\left(80 \times 10^{3}\right.$ cells $/ \mathrm{mL}$ ) was maintained during the second experiment. In this experiment, neither DGC nor AGR were affected by changing the concentration of $T$. chuii (Table 3). After $168 \mathrm{~h}$, more than $50 \%$ of the larvae from all treatments had reached postlarvae stage, regardless of cell concentrations $(P>0.05$ Table 4). These findings were similar to those of the first experiment with larvae fed $80 \times 10^{3}$ cell $/ \mathrm{mL}$ or more cells $/ \mathrm{mL}$ of $C$. gracilis. The larvae's resistance to salinity shock also remained unaffected by variation in $T$. chuii concentration (Table 3 ). Survival rates of the larvae fed flagellate at different cell concentrations differed in a range between $68.7 \pm 1.5$ and $89.4 \pm 0.8 \%(P>0.05$ Table 3$)$.

\section{Experiment 3}

At a constant cell concentration for both microalgae $\left(80 \times 10^{3}\right.$ cells $/ \mathrm{mL}$ for $C$. gracilis and $2 \times 10^{3}$ cells $/ \mathrm{mL}$ for $T$. chuii), the best DGC values $\left(31.4 \pm 0.4 \mu \mathrm{g}\right.$ live weight day $\left.{ }^{-1}\right)(P<0.05)$ were achieved with larvae fed 4 Artemia $\mathrm{NA} / \mathrm{mL}$ (Table 5). However, AGR values were not significantly different $(P>0.05)$ between all Artemia NA concentrations tested (Table 5). 
DI values did not vary significantly with an increase in Artemia NA concentration and remained equal for all treatments. Larvae from all replicates reached the postlarval stage within $72 \mathrm{~h}$ from the $M_{1}$ stage (Table 6). There were no significant differences in survival rates and tolerance to salinity shock among the various treatments (Table 5 ). The postlarvae's resistance to salinity shock (QI) for all treatments showed values between $94.5 \pm 0.1$ and $98.4 \pm 0.7 \%$ survival $(P>$ 0.05 , Table 5).

\section{Discussion}

The best cell concentration for each kind of live food were selected using the combination of maximum survival percentage, DGC, and DI values as criteria, generating a feeding schedule for F. brasiliensis larvae (Table 7). The ultimate test of suitable nutrition was the production of somatic tissues and consequent larval development, which can be summarized by this statement, "larvae that grow well, survive well" (Jones et al. 1997). The concentration of $C$. gracilis that resulted in the highest $F$. brasiliensis larvae weight gain was $80 \times 10^{3}$ cells $/ \mathrm{mL}$. It also provided the best conditions for survival, AGR, and DI, which improved with the availability of diatoms. As would be expected at low levels of inclusions, at the low cell concentration $(20 \mathrm{x}$ $10^{3}$ cells $/ \mathrm{mL}$ of $C$. gracilis), larvae remained at the $P z_{1}$ stage for an extra day and refrained from feeding. Subsequently, they remained in the $P \mathrm{Z}_{1}$ to $P \mathrm{Z}_{2}$ stage for an abnormally long period or faced mortality during the next change from the $\mathrm{PZ}_{3}$ to $\mathrm{M}_{1}$ stage. These low growth rates can be explained by the inability of $C$. gracilis, at low concentrations, to provide essential nutrients at the start of larval development. The use of salinity shock is a good measure of the fitness of larvae and is often utilized as a measure of larval quality. In the present experiment, the QI data indicated that larvae fed 40 to $60 \times 10^{3}$ cells $/ \mathrm{mL}$ of $C$. gracilis (Table 1) had the best resistance to salinity change. However, DGC and DI values were significantly lower when compared with the feed containing $80 \times 10^{3}$ cells $/ \mathrm{mL}$.

Similar results were reported in Penaeus monodon postlarvae fed n-3-HUFA enriched Artemia NA (Rees et al. 1994). Shrimp that achieved the highest growth rate were less resistant than small individuals to the salinity test. It appears that supplying postlarvae with a diet high in HUFA's may affect the balance among some physiological functions and growth-related activities (e.g. molting, cellular proliferation). As with $P$. monodon, an excess of dietary lipid in $F$. brasiliensis postlarvae fed high a concentration of both $C$. gracilis $\left(80 \times 10^{3}\right.$ and $100 \times 10^{3}$ cells $/ \mathrm{mL})$ and $T$. chuii $\left(5 \times 10^{3}\right.$ to $7 \times 10^{3}$ cells $\left./ \mathrm{mL}\right)$ could affect the balance between growth and other physiological functions. Both microalgae contained around $13 \%$ lipid, but eicosapenthanoic acid (EPA), docohexaenoic acid (DHA), and arachidonic acid (AA) concentrations in HUFA's for diatoms were $3 \%, 20 \%$, and $2 \%$ and for flagellates were $4 \%, 3 \%$, and $1 \%$ respectively (Brown et al. 1997).

Compared with other species, F. brasiliensis larvae showed an optimum $C$. gracilis cell concentration higher than that reported for F. duorarum $\left(50 \times 10^{3}\right.$ cells $\left./ \mathrm{mL}\right)$ (Durruty 1993) and lower than those reported for $F$. paulensis (Alfonso and Silva 1992). The optimum cell concentration $\left(80 \times 10^{3}\right.$ cells $/ \mathrm{mL}$ ) reported here was twice that reported for L. setiferus (Gallardo et al. 1995) and L. schmitti (Alfonso and Gelabert 1986). Present results suggest that if concentrations, used by these authors, were applied to $F$. brasiliensis larvae, poorer results should be expected. $F$. brasiliensis larvae were raised successfully with two microalgal species and monitoring showed an adequate nutrient supply, both in quality and quantity, during a complete larval period.

The absence of statistical differences observed in responses for survival, DGC, AGR, and DI measured at varying concentrations of $T$. chuii indicated that no improvement could be reached with an increase in cell concentration. Therefore, the lowest cell concentration $\left(2 \times 10^{3} \mathrm{cells} / \mathrm{mL}\right)$ 
could be used as the flagellate's optimum in the feeding schedule of $F$. brasiliensis larvae. In this study, QI improved $100 \%$ when $T$. chuii was included in the larvae regime with a cell concentration of at least $2 \times 10^{3}$ cells $/ \mathrm{mL}$. Similar results were achieved with $L$. setiferus larvae (Gallardo et al. 1995).

The nutritional value of $T$. chuii for shrimp larvae has been a topic of discussion in the literature. Several researchers reported that $T$. chuii could be eliminated from the feeding regime of shrimp larvae (Kuban et al. 1985; Holloway and Hopkins 1987). However, others concluded that diatoms had a positive and significant impact on larvae nutrition only when complemented by flagellates in an appropriate feeding schedule (Quinitio and Villegas 1982; Alfonso et al. 1988). The optimum $T$. chuii cell concentration $\left(2 \times 10^{3} \mathrm{cells} / \mathrm{mL}\right)$ for $F$. brasiliensis was higher than that previously reported for $L$. setiferus $\left(1 \times 10^{3}\right.$ cells $\left./ \mathrm{mL}\right)$ (Gallardo et al. 1995), and lower than those reported for $F$. aztecus, at $50 \times 10^{3} \mathrm{cells} / \mathrm{mL}$, (Kuban et al. 1985), for $P$. indicus, at $25 \times 10^{3}$

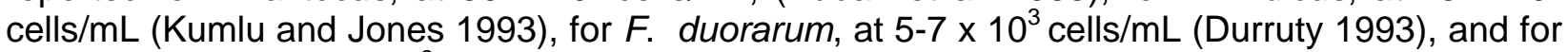
L. stylirostris, at 5-10 × 103 cells/mL (Ottogalli 1991).

Artemia NA results produced the best DGC at a concentration of $4 \mathrm{NA} / \mathrm{mL}$, but AGR and DI were not statistically different. Inclusion of Artemia NA under controlled rearing conditions fit the natural feeding habits of the later larval stages. Feeding habits of shrimp vary during larval development as a result of several metamorphic changes. Filter-feeding habit is well pronounced during the protozoea stages, however it is replaced by a raptorial feeding habit during mysis stages in L. setiferus larvae (Lovett and Felder 1989) whereas $P$. monodon larvae it was observed since protozoea stages (Kumarly et al. 1989). The shift from filter to raptorial feeding produces a distinct energy benefit during the $M_{1}-M_{2}$ larval stage (Jones et al. 1997).

In summary, under the reported condition $F$. brasiliensis larvae reached a maximum weight of around $200 \mu \mathrm{g}$ and high algae densities resulting in reduce weights. However, length increase followed the gradient of algae concentrations. Therefore, food should include at least $80 \times 10^{3}$ cells $/ \mathrm{mL}$ of $C$. gracilis. Lower cell concentrations of this microalgae affected survival, growth, and development of larvae significantly showing $F$. brasiliensis's strong dependence on it. A combination of $C$. gracilis and $T$. chuii was optimum for larval development when $T$. chuii was maintained at the lowest tested concentration $\left(2 \times 10^{3}\right.$ cells $\left./ \mathrm{mL}\right)$. Artemia at a density of $4 \mathrm{NA} / \mathrm{mL}$ can effectively satisfy animal protein requirements during the mysis stages.

\section{Acknowledgments}

We thank CONACyT (FOSIIERRA) for financial support (Project No. 990619), Biologist Manuel Puerto and Martha Sandoval, M.S. (Centro de Investigaciones Pesqueras de Puerto Morelos, Instituto Nacional de la Pesca) supplied wild broodstock, Wilberth Martínez, Francisco RamónRamírez, Gemma Martínez assisted during experiments; UMDI-Sisal technicians Gabriela Palomino, Adriana Paredes assisted to produce live food and larvae.

\section{Literature Cited}

Alfonso, E. and R. Gelabert. 1986. Metodología para la producción de postlarvas del camarón blanco Penaeus schmitti. Revista de Investigaciones Marinas 7(1):43-50.

Alfonso, E., L. Martínez, R. Gelabert, and S. Leal. 1988. Alimentación de larvas del camarón Penaeus schmitti_(Diatomeas y flagelados) Revista de Investigaciones Marinas 9 (1):47-58.

Alfonso, E., and D. Silva. 1992. Alimentación de larvas de camarón Penaeus paulensis con las diatomeas Plagiogramma $s p$. y Chaetoceros gracilis. Revista de Investigaciones Marinas. 13(2):147-151.

Anguiano, O, L.1999, Algunos aspectos preliminares del potencial del camarón rojo del caribe Mexicano Farfantepeneus brasiliensis (Maduración, desarrollo larval, y engorda), Tesis de 
Licenciatura, Facultad de ciencias Pesqueras, Universidad Autónoma del Carmen, México, 60 pp.

Aquacop. 1983. Penaeid larval rearing in the Center Océanologique du Pacifique, Crustacean Aquaculture. Pages123-127 in J.P. Mc Vey editor. CRC Handbook of mariculture volumen I, Crustacean Aquaculture, CRC Pess, Inc. Boca Raton, Florida, USA.

Aujero, E.J., T. Millena, T. Tech, and S. Javellana. 1983. Nutritional value of five marine phytoplankton species isolated from Philippines waters as food for the larvae of Penaeus monodon. First International Biennial Conference on Warm Water Aquaculture Crustacea in BYU-Hawaii: 1-17.

Brown, M.R .1991. The amino acid and sugar composition of 16 species of microalgae used in mariculture. Journal of Experimental Marine Biology 145: 79-99.

Brown, M.R., S.W. Jeffrey, J.K. Volkman, and G.A. Dunstan. 1997. Nutritional properties of microalgae for mariculture. Aquaculture 151: 315-351.

Bureau, D.P., P.A. Azevedo, M. Tapia-Salazar, and G. Cuzon. 2000. Pattern and cost of growth and nutrient deposition in fish and shrimp: Potential implications and applications: In CruzSuárez, E., Ricque-Marie, D., Tapia-Salazar, M. and Civera-Cerecedo, R. (Eds) Avances en Nutrición acuícola V. Memorias del SINA V, 19 al 12 de Noviembre, 2000, Mérida Yucatán, México 2000, 111-140.

Durruty, C.V. 1993. Ingestión, desarrollo, crecimiento y sobrevivencia de las larvas de Penaeus duorarum_alimentadas con distintas concentraciones de algas. Tesis Profesional, Facultad de Ciencias, Universidad Nacional Autónoma de México, 53 pp.

Emmerson, W.D. 1980. Ingestion, growth and development of Penaeus indicus larvae as function of Thalassiosira weissflogii cell concentration. Marine Biology 58:65-73.

Gallardo, P.P., E. Alfonso, G. Gaxiola, L.A. Soto, and C. Rosas. 1995. Feeding schedule of Penaeus setiferus larvae based on diatoms (Chaetoceros ceratosporum), flagellates (Tetraselmis chuii) and Artemia nauplii. Aquaculture 131: 239-252.

Holloway, J.D. and J.S. Hopkins. 1987. Survival and metamorphosis of larval Penaeus vannamei and Penaeus monodon fed natural and artificial diets. Annual Meeting of S.C. Fisheries Workers Association, Charleston, S.C. 10pp.

Jones D.A., A. B. Yule, and D.L. Holland. 1997. Larval Nutrition. Pages 353-389. in L. R. D'Abramo, D.E. Conklin and D.M. Akiyama, editors. Crustacean Nutrition Advances in World Aquaculture Vol 6. The World Aquaculture Society, Baton Rouge, Louisiana, USA.

Kattner, G., I.S Wehrtmann, and T. Merck. 1994. Inter annual variations of lipids and fatty acids during larval development of Crangon spp. in the German Bight, North Sea. Comparative Biochemistry and Physiology 107 B(1): 103-110.

Kuban, F.D., A.L. Lawrence, and J.S. Wilkenfeld. 1985. Survival, metamorphosis and growth of larvae from four Penaeid species fed six food combinations. Aquaculture 47: 151-162.

Kumlu, M. and D.A. Jones, 1993. Optimum rearing conditions for Penaeus indicus larvae reared in the laboratory. European Aquaculture Society, Special publication19: 142.

Kurmaly, K., A.B. Yule, and D.A. Jones. 1989. An energy budget for the larvae of Penaeus monodon (Fabricius). Aquaculture 81: 13-25.

Leal S., E. Alfonso, and A. Gainza. 1985. Recomendaciones sobre la alimentación de larvas de camarones Penaeus notialis y Penaeus schmitti en cultivo. Revista de Investigaciones Marinas 6 (1): 87-91.

Leger, P. and P. Sorgeloss. 1992. Optimized feeding regimes in shrimp hatcheries. Pages 225244 In: A.W. Fast and L.J. Lester, editors. Marine Shrimp Culture Principles and Practices. Elsevier Science Publisher B.V., St. Louis, MO, USA.

López, N. A. 1988. Densidad optima de alimento vivo para las larvas de camarón rosado Penaeus duorarum Burkerroad, 1939, y su posible sustitución con alimento micro encapsulado. Tesis de Maestría en Ciencias (Biología), Facultad de Ciencias, Universidad Nacional Autónoma de México. 78pp. 
Lovett, D. and D. Felder.1989. Ontogeny of morphology in the white shrimp Penaeus setiferus (Decapoda, Penaeidae). Journal of Morphology 201: 253-272.

Ottogalli, L., 1991. Total substitution of microparticles for algae for Penaeus stylirostris larval rearing in New Caledonia. J. World Aquaculture Society, 22:46A.

Perez Farfante, I. and B. Kensley. 1997. Penaeoid and segestoid shrimps and prawns of the World: Keys and Diagnoses for the Families and genera. Mémoires du Museum National d'Histoire Naturelle Tome 175 Zoologie, Paris, pp 225.

Quinito, E. and C.T. Villegas, 1982. Growth, survival and macronutrient composition of Penaeus monodon Fabricius larvae fed with Chaetoceros calcitrans and Tetraselmis chuii. Aquaculture 29:256-260.

Rees, J.F., K Curé, S. Piyatiratitivoracul, P. Menasveta, and P. Sorgeloos. 1994. Osmotic stress resistance as a quality diagnostic for penaeid postlarvae. Pages 1025-1028 In: L.M. Chou, A.D. Munro, T.J. Lam, T.W. Chen, K.K.L. Cheong, J.K. Ding, K.K. Hooi, H.W. Khoo, V.P.E. Phang, K.F. Shim and C.H. Fan, editors. The Third Asian Fisheries Forum. Asian Fisheries Society, Manila, Philippines.

Rodriguez, A., L. Le Vay, G. Mourente, and D.A. Jones. 1994. Biochemical composition and digestive enzyme activity in larvae and postlarvae of Penaeus japonicus during herbivorous and carnivorous feeding. Marine Biology 118: 45-51.

Seafdec. 1984. A guide to prawn hatchery design and operation. Aquaculture department of Southeast Asian Fisheries Development Center 9: 42 pp.

Simon Clyde M. 1978. The culture of the diatom Chaetoceros gracilis and its use as a food for peneid protozoeal larvae. Aquaculture 14: 105-113.

Souza, F.M.L. and G. Kelly. 2000. Effects of a diet of a nitrogen -limited alga (Tetraselmis suecica) on growth, survival and biochemical composition of tiger prawn (Penaeus semisulcatus) larvae. Aquaculture 181: 311-329.

Teshima, S. 1997. Phospholipids and sterols. Pages 85-107 In: L.R. d'Abramo, D.E. Conklin and D.M. Akiyama, editors. Crustacean Nutrition Advances in World Aquaculture Vol 6. The World Aquaculture Society, Baton Rouge, Louisiana, USA.

Villegas, C.T., and A. Kanazawa. 1979. Relationship between diet composition and growth of the zoeal and mysis stages of Penaeus japonicus Bate. Fisheries Research Journal Philippines 4: 3240.

Yufera, M., A. Rodríguez and L.M. Lubian. 1984. Zooplancton ingestion and feeding behavior of Penaeus kerathurus larvae reared in the laboratory. Aquaculture 42(3): 217-224.

Zar, J.H. 1996. Biostatistical Analysis. Prentice Hall. New Jersey. USA. 
Table 1. Daily growth coefficient (DGC), absolute growth rate (AGR), survival percentage and quality index (QI) of Farfantepenaeus brasiliensis larvae fed with five different concentrations of Chaetoceros gracilis (Experiment 1). MeantSE based on three replicates. Different letters in each row show significant differences $(\mathrm{P}<0.05)$.

\begin{tabular}{|c|c|c|c|c|c|}
\hline \multirow[b]{2}{*}{ V } & \multicolumn{5}{|c|}{ Treatments (cell/mL) } \\
\hline & $20 \times 10^{3}$ & $40 \times 10^{3}$ & $60 \times 10^{3}$ & $80 \times 10^{3}$ & $100 \times 10^{3}$ \\
\hline $\mathrm{DGC}(\mu \mathrm{g} / \mathrm{d})$ & $35.7 \pm 3.4^{d}$ & $43.9 \pm 2.9^{b c}$ & $45.5 \pm 1.2^{\text {bc }}$ & $53.1 \pm 0.5^{a}$ & $50.7 \pm 1.0^{\mathrm{ab}}$ \\
\hline AGR $(\mu \mathrm{m} / \mathrm{d})$ & $475.6 \pm 0.0^{b}$ & $516.1 \pm 26.9^{b}$ & $595.6 \pm 16.4^{b}$ & $702.1 \pm 23.2^{a}$ & $717.5 \pm 45.1^{a}$ \\
\hline Survival (\%) & $33.8 \pm 6.8^{b}$ & $52.5 \pm 10.6^{a b}$ & $70.9 \pm 4.6^{\mathrm{ab}}$ & $81.5 \pm 16^{a b}$ & $84.5 \pm 9^{a b}$ \\
\hline Ql (\%) & $53.3 \pm 11.7^{b}$ & $85.5 \pm 9.5^{\mathrm{ab}}$ & $98.9 \pm 1^{a}$ & $52.8 \pm 18^{b}$ & $39.9 \pm 20^{b}$ \\
\hline
\end{tabular}

Table 2. Development index (DI) for Farfantepenaeus brasiliensis larvae fed with five different cell concentrations of the diatom Chaetoceros gracilis (Experiment 1). MeanะSE based on three replicates. Different letters in the same row indicate significant differences ( $\mathrm{P}<0.05)$.

\begin{tabular}{|c|c|c|c|c|c|}
\hline \multirow[b]{2}{*}{ Hours } & \multicolumn{5}{|c|}{ Treatments (cell/mL) } \\
\hline & $20 \times 10^{3}$ & $40 \times 10^{3}$ & $60 \times 10^{3}$ & $80 \times 10^{3}$ & $100 \times 10^{3}$ \\
\hline 0 & $1 \pm 0^{a}$ & $1 \pm 0^{a}$ & $1 \pm 0^{a}$ & $1 \pm 0^{a}$ & $1 \pm 0^{a}$ \\
\hline 24 & $1.1 \pm 0.1^{a}$ & $1.9 \pm 0.1^{b}$ & $2 \pm 0^{b}$ & $2 \pm 0^{b}$ & $2 \pm 0^{b}$ \\
\hline 48 & $2 \pm 0^{a}$ & $2 \pm 0^{a}$ & $2.3 \pm 0.12^{b}$ & $2.6 \pm 0.1^{\circ}$ & $2.9 \pm 0.1^{\circ}$ \\
\hline 72 & $2.4 \pm 0.13^{a}$ & $2.7 \pm 0.1^{a}$ & $3 \pm 0^{b}$ & $3 \pm 0^{b}$ & $3 \pm 0^{b}$ \\
\hline 96 & $2.8 \pm 0.14^{a}$ & $3 \pm 0^{a}$ & $3.7 \pm 0.125^{b}$ & $4 \pm 0^{\circ}$ & $4 \pm 0^{\circ}$ \\
\hline 120 & $2.9 \pm 0.1^{a}$ & $3.7 \pm 0.2^{b}$ & $4.5 \pm 0.3^{\circ}$ & $4.9 \pm 0.1^{d}$ & $5 \pm 0^{d}$ \\
\hline 144 & $3.1 \pm 0.1^{a}$ & $4.5 \pm 0.2^{b}$ & $5.3 \pm 0.2^{\circ}$ & $6 \pm 0^{d}$ & $6 \pm 0^{d}$ \\
\hline 168 & $3.9 \pm 0.1^{a}$ & $5.3 \pm 0.2^{b}$ & $6.53 \pm 0.1^{c}$ & $6.9 \pm 0.1^{d}$ & $7 \pm 0^{d}$ \\
\hline 192 & $4.9 \pm 0.2^{a}$ & $6.3 \pm 0.3^{b}$ & $7 \pm 0^{\circ}$ & & \\
\hline 216 & $5.4 \pm 2.3^{a}$ & $7.0 \pm 0^{b}$ & & & \\
\hline
\end{tabular}


Table 3. Daily growth coefficient (DGC), absolute growth rate (AGR), survival percentage and quality index (QI) Farfantepenaeus brasiliensis larvae fed with five different concentrations of Tetraselmis chuii (Experiment 2). MeantSE based on three replicates. Different letters in each row show significant differences $(\mathrm{P}<0.05)$.

\begin{tabular}{|c|c|c|c|c|c|}
\hline \multirow[b]{2}{*}{ v } & \multicolumn{5}{|c|}{ Treatments (cell/mL) } \\
\hline & $2 \times 10^{3}$ & $4 \times 10^{3}$ & $6 \times 10^{3}$ & $8 \times 10^{3}$ & $10 \times 10^{3}$ \\
\hline$\overline{\mathrm{DGC}}(\mu \mathrm{g} / \mathrm{d})$ & $45.5 \pm 3.5^{a}$ & $38.05 \pm 4.3^{a}$ & $41.2 \pm 0.5^{a}$ & $40.5 \pm 1.2^{a}$ & $39.5 \pm 0.9^{a}$ \\
\hline AGR $(\mu \mathrm{m} / \mathrm{d})$ & $707.0 \pm 5.8^{a}$ & $702.0 \pm 42.5^{a}$ & $735.0 \pm 5.2^{a}$ & $692.0 \pm 19.1^{a}$ & $728.0 \pm 12.0^{a}$ \\
\hline Survival (\%) & $78.5 \pm 14^{a}$ & $68.7 \pm 1.5^{a}$ & $78.7 \pm 0.01^{a}$ & $73.8 \pm 1.5^{a}$ & $89.4 \pm 0.8^{a}$ \\
\hline Ql (\%) & $100 \pm 0^{a}$ & $99.4 \pm 1.5^{a}$ & $99.7 \pm 0.6^{a}$ & $98.4 \pm 1.4^{a}$ & $99.9 \pm 0.2^{a}$ \\
\hline
\end{tabular}

Table 4. Deve/opment index (DI) values of Farfantepenaeus brasiliensis larvae fed with five different cell concentrations of the flage/late Tetraselmis chuii (Experiment 2). Meant SE based on three replicates. Different letters in the same row indicate significant differences ( $\mathrm{P}<0.05$ ).

\begin{tabular}{|c|c|c|c|c|c|}
\hline \multirow[b]{2}{*}{ Hours } & \multicolumn{5}{|c|}{ Treatments (cell/mL) } \\
\hline & $2 \times 10^{3}$ & $4 \times 10^{3}$ & $6 \times 10^{3}$ & $8 \times 10^{3}$ & $10 \times 10^{3}$ \\
\hline 0 & $1 \pm 0^{a}$ & $1 \pm 0^{a}$ & $1 \pm 0^{a}$ & $1 \pm 0^{a}$ & $1 \pm 0^{a}$ \\
\hline 24 & $1.9 \pm 0.1^{a}$ & $1.5 \pm 0.26^{a}$ & $1.5 \pm 0.1^{a}$ & $1.5 \pm 0.2^{a}$ & $1.4 \pm 0.2^{a}$ \\
\hline 48 & $2 \pm 0^{a}$ & $2 \pm 0^{a}$ & $2 \pm 0^{a}$ & $2 \pm 0^{a}$ & $2 \pm 0^{a}$ \\
\hline 72 & $3 \pm 0^{a}$ & $3 \pm 0^{a}$ & $3 \pm 0^{a}$ & $3 \pm 0^{a}$ & $3 \pm 0^{a}$ \\
\hline 96 & $4 \pm 0^{a}$ & $3.7 \pm 0.26^{a}$ & $4 \pm 0^{a}$ & $4 \pm 0^{a}$ & $4 \pm 0^{a}$ \\
\hline 120 & $4.7 \pm 0.1^{a}$ & $4.5 \pm 0.33^{a}$ & $4.8 \pm 0^{a}$ & $4.9 \pm 0.13^{a}$ & $5 \pm 0^{a}$ \\
\hline 144 & $5.8 \pm 0^{a}$ & $5.7 \pm 0.24^{a}$ & $5.7 \pm 0.24^{a}$ & $5.7 \pm 0.24^{a}$ & $6 \pm 0^{a}$ \\
\hline 168 & $6.7 \pm 0.13^{a}$ & $6.7 \pm 0.26^{a}$ & $6.9 \pm 0.13^{a}$ & $6.6 \pm 0.30^{a}$ & $7 \pm 0^{a}$ \\
\hline
\end{tabular}


Table 5. Daily growth coefficient (DGC), absolute growth rate (AGR), survival percentage and quality index (QI) for Farfantepenaeus brasiliensis larvae fed with five different concentrations of Artemia franciscana (Experiment 3). MeantSE based on three replicates. Different letters in each row show significant differences $(\mathrm{P}<0.05)$.

\begin{tabular}{|c|c|c|c|c|c|}
\hline \multirow[b]{2}{*}{ V } & \multicolumn{5}{|c|}{ Treatments (NA/mL) } \\
\hline & 1 & 2 & 3 & 4 & 5 \\
\hline DGC ( $\mu \mathrm{g} / \mathrm{d})$ & $25.5 \pm 1.8^{a b}$ & $19.8 \pm 1.4^{b}$ & $26.6 \pm 0.8^{a b}$ & $31.4 \pm 0.4^{a}$ & $23.4 \pm 3.3^{b}$ \\
\hline AGR ( $\mu \mathrm{m} / \mathrm{d})$ & $690.0 \pm 58^{a}$ & $735.0 \pm 20^{a}$ & $776.0 \pm 34^{a}$ & $742.0 \pm 33^{a}$ & $788.0 \pm 13^{a}$ \\
\hline Survival (\%) & $91 \pm 4^{a}$ & $96.6 \pm 2.8^{a}$ & $93.8 \pm 1.2^{a}$ & $98.3 \pm 2.9^{a}$ & $65.4 \pm 1.4^{a}$ \\
\hline Ql (\%) & $96.2 \pm 1.6^{a}$ & $97.2 \pm 1.5^{a}$ & $97.2 \pm 1.5^{a}$ & $94.5 \pm 0.1^{a}$ & $98.4 \pm 0.7^{a}$ \\
\hline
\end{tabular}

DI values did not vary significantly with an increase in Artemia NA concentration and remained equal for all treatments. Larvae from all replicates reached the postlarval stage within $72 \mathrm{~h}$ from the $M_{1}$ stage (Table 6). There were no significant differences in survival rates and tolerance to salinity shock among the various treatments (Table 5). The postlarvae's resistance to salinity shock (Ql) for all treatments showed values between $94.5 \pm 0.1$ and $98.4 \pm 0.7 \%$ survival $(P>0.05$, Table 5 .

Table 6. Development index (DI) for the larvae of Farfantepenaeus brasiliensis fed with five different concentrations of the Artemia nauplii (Experiment 3). Meant SE based on three replicates. Different letters in the same row indicate significant differences (P < 0.05).

\begin{tabular}{lccccc}
\hline & \multicolumn{5}{c}{ Treatments (NA/mL) } \\
\cline { 2 - 7 } Hours & $\mathbf{1}$ & $\mathbf{2}$ & $\mathbf{3}$ & $\mathbf{4}$ & $\mathbf{5}$ \\
\hline 0 & $4 \pm 0^{a}$ & $4 \pm 0^{a}$ & $4 \pm 0^{a}$ & $4 \pm 0^{a}$ & $4 \pm 0^{a}$ \\
24 & $5 \pm 0^{a}$ & $5 \pm 0^{a}$ & $5 \pm 0^{a}$ & $5 \pm 0^{a}$ & $5 \pm 0^{a}$ \\
48 & $6 \pm 0^{a}$ & $6 \pm 0^{a}$ & $6 \pm 0^{a}$ & $5.7 \pm 0.33^{a}$ & $6 \pm 0^{a}$ \\
72 & $7 \pm 0^{a}$ & $7 \pm 0^{a}$ & $7 \pm 0^{a}$ & $7 \pm 0^{a}$ & $7 \pm 0^{a}$ \\
\hline
\end{tabular}

